\title{
3D-Analysis of Soil-Foundation-Structure Interaction in Layered Soil
}

\author{
Mohd Ahmed1*, Mahmoud H. Mohamed ${ }^{2}$, Javed Mallick³ ${ }^{3}$ Mohd Abul Hasan ${ }^{4}$ \\ Civil Engineering Department, Faculty of Engineering, King Khalid University, Abha, KSA \\ Email: moahmedkku@gmail.com
}

Received 26 September 2014; revised 22 October 2014; accepted 20 November 2014

Copyright (C) 2014 by authors and Scientific Research Publishing Inc.

This work is licensed under the Creative Commons Attribution International License (CC BY). http://creativecommons.org/licenses/by/4.0/

(c) (i) Open Access

\begin{abstract}
The analysis of building structure in contact with soil involves an interactive process of stresses and strains developed within the structure and the soil field. The response of Piled-Raft Foundation system to the structure is very challenging because there is an important interplay between the component of building structure and the soil field. Herein, soil-foundation-structure interaction of buildings founded on Piled-Raft Foundation is evaluated through 3D-Nonlinear Finite Element Analyses using PLAXIS3D FOUNDATION code. The soil settlements and forces demand of the high-rise building structures and foundation is computed. The parametric study affecting the soilfoundation-structure response has been carried out. The parameters such as construction phasing, sequential loading, building aspect ratios, soil failure models and thickness proportion of soil field stiff layer, are considered. It is concluded that the interaction of building foundation-soil field and super-structure has remarkable effect on the structure.
\end{abstract}

\section{Keywords}

Foundation, Piled-Raft Foundation, Soil Models, Soil Field, Finite Element Method, Sequential Loading, Construction Phase

\section{Introduction}

The analysis of Piled-Raft Foundation is very challenging because the load in the piled-raft structures is transferred to the soil not only by the interaction between the soil and the piles but also by the interaction between foundation structure and superstructure. In this interaction, deformations in the soils are the key factor which will affect forces and deformation in foundation and superstructure. The soils below the ground level are heterogeneous and often found as layered system, i.e. layer wise varying properties below the ground. The combined

${ }^{*}$ Corresponding author. 
piled-raft foundation penetrates deep into the foundation soil increasing its significant depth below the ground and affects the response of structure and soil. The method of analysis of foundation and structure also affects the response of structure and soil. The complex foundation system requires a reliable advance computational method that can simulate the 3D-non-linear soil behavior and structure-foundation system interaction. Considerable attention has been paid to analyze, design and construction of combined piled-raft foundation (CPRF) system. The survey of various analytical methods and numerical methods used to model the behavior of geomechanics has been presented by [1]. The various aspects contributed in reference to piled-raft foundation design have been compiled by Hemsley [2]. Ahmed et al. [3] has pointed out the recent advances in the piled-raft foundation system. Lin and Feng [4] have presented piled-raft analysis output for settlement, bending moment both in pile and raft, and effects of raft flexibility for vertical uniform loading in the subsoil. For the case of piled raft placed over soft clay layer, the contact pressure is merely $4 \%-6 \%$, whereas it is $15 \%-25 \%$ if the piled raft resting on sand layer at ground surface. Rabiei [5] has carried out the parametric study on piled-raft foundation design. The parameter studied were pile length and spacing, number of piles, raft thickness, pile-soil and raft-soil stiffness ratio and pile-raft interaction. They concluded that by ignoring the interactions involved in the piled raft system, may lead to serious underestimates of settlement and also lead to inaccurate estimates of raft bending moments and pile loads. Singh and Singh [6] demonstrated that ignoring the interactions between the piled raft foundations elements may lead to a very serious over-estimate of the stiffness of the foundation. The case studies on optimized piled-raft foundation performance comprising of connected and non-connected piles using simple 2D analysis are presented by Eslami et al. [7]. A simplified procedure applicable has been presented by Kapackci and Ozkan [8] for estimation of piled-raft settlement. Nguyen et al. [9] has proposed a simplified design approach of piled-raft foundations under vertical load considering interaction effects. They compared the results of method with experimental and other numerical results and found good agreement between the results. The optimization study of piled-raft foundation systems has been carried out by Horikoshi and Randolph [10]. It is experimentally demonstrated that model rafts, founded on structurally disconnected pile reinforced sand, will have reduced settlement and bending moments [11]. Field measurements of the load observed for the raft and the piles of piled-raft foundation on stiff clays at working conditions are reported by Cooke [12]. They suggest that the ratio of load in the most heavily loaded piles in the perimeter of the group to that in the least heavily loaded pile near the centre could be about 2.5. A displacement based design procedure is proposed by Prakoso and Kulhawy [13] for piled-raft foundation based on the results of simplified linear elastic and nonlinear plane strain piled-raft finite element models. The effect of raft and pile group compression capacity was evaluated on the raft settlements, raft bending moments, and pile-raft load transfer ratio. Mahmood and Ahmed [14] have carried out the dynamic analysis of framed including the soil-structure interaction effects and concluded that the soil-structure interaction problem can have beneficial effects on the structural behavior when non-linear soil models and interface conditions are considered. Shayea and Zeedan [15] have presented a new approach for the design of raft foundation using 3-D modelling of each part of the whole structure (superstructure, raft and the soil) and considering the soil structure interaction. They developed charts to show the relationship between thickness of raft and number of design parameters including soil type.

From the literature survey it is clear that the interaction of the superstructure in the soil-foundation analysis has not been taken into consideration in most of the research work and load from the super structure in considered acting directly on the raft as a uniform or concentrated load. The effect of construction phase and mode of superstructure loading on the response of structure and foundation has not been given due attention. In this paper, complete soil-structure interaction of combined Piled-Raft Foundation with the foundation soil and superstructure of the building is evaluated through 3D-nonlinear Finite Element Analyses using PLAXIS3D foundation code [16]. The different parameters affecting the soil-foundation-structure response, such as building aspect ratios, mode of load application to foundation soil, soil failure criteria of soil field and proportional thickness ratio of stiff soil in two-layer soil stratum is studied. The displacements and load demands imposed on the high-rise building structures having piled-raft foundation are computed. The most of the previous studies on soil-piled-raft foundation analysis are based on direct loading of superstructure on raft and without considering interaction of superstructure and foundation. The foundation soil in piled-raft foundation-soil models without including super structure will be stiffer than models with the one-phase super structure loading or sequential super structure loading. The foundation structure and soil field response is significantly affected by different building structure shape and soil failure models. The soil field response in layered soil is also affected by presence of lesser stiff layer below the raft. It is also observed effect on deflection and forces of superstructure components due to inclusion of loading phases in piled-raft foundation interaction analysis. 


\section{Statement of the Problem}

A 15-storey square/rectangular building having piled raft foundation in the two layered soil system is selected for the complete structure-foundation interaction analysis. The square building (aspect ratio =1) has 4 bays in $\mathrm{X}$-and Y-direction and the rectangular building (aspect ratio $=1.75$ ) has 3 bays in X-direction and 6 bays in Y-direction as shown in Figure 1. Buildings have nearly the same plan area. The ground and typical floors are $6.0 \mathrm{~m}$ and $3.0 \mathrm{~m}$ high respectively. The structural system of all floors is a flat concrete slab type of $200 \mathrm{~mm}$ thickness subjected to a total uniform load of $15 \mathrm{kN} / \mathrm{m}^{2}$. Dimensions of columns are listed in Table 1 . The concrete raft is assumed to be at a depth 2.0 (m) beneath the ground surface and has $1.5(\mathrm{~m})$ thicknesses. The plan dimension of square raft is $25 \mathrm{~m} \times 25 \mathrm{~m}$ with overhang of $2.5 \mathrm{~m}$ while the plan dimension of rectangular raft is $19.2 \mathrm{~m} \times 33.6 \mathrm{~m}$ with overhang of $2.4 \mathrm{~m}$. The estimated total vertical load on square and rectangular rafts is 138.8 MN. A total of 25 circular concrete piles of $0.75 \mathrm{~m}$ diameter are located under the raft for each building structure. Modulus of elasticity of concrete is assumed as $3.4 \times 107 \mathrm{kN} / \mathrm{m}^{2}$ while concrete Poisson's ratio and density is considered in structural models as 0.2 and $25 \mathrm{kN} / \mathrm{m}^{3}$ respectively. The typical floor plans and foundation plans having raft with pile location of square and rectangular shaped building are shown in Figure 1.

The slenderness ratio (L/D) of piles is taken as 26.7 and end tip of the piles are considered resting on the bottom surface of top soil layer having hardening soil model for different aspect of building, mode of application
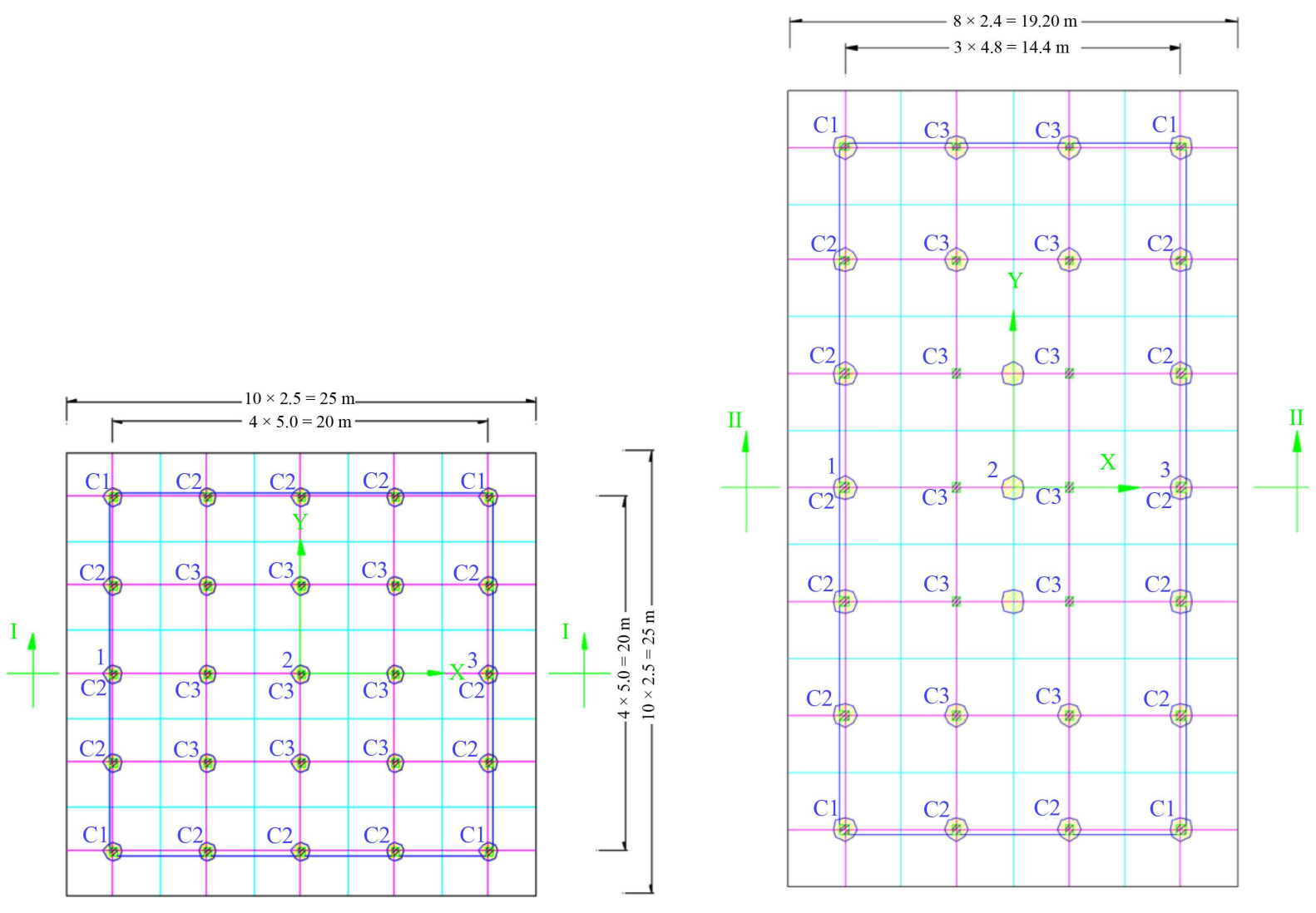

Figure 1. Typical floor and raft-pile plans of buildings.

Table 1. Dimension of columns in buildings.

\begin{tabular}{cccc}
\hline \multirow{2}{*}{ Building Shape } & & Column Dimensions $(\mathrm{m} \times \mathrm{m})$ & \\
\cline { 2 - 4 } & $\mathrm{C} 1$ & $0.75 \times 0.75$ & C2 \\
Square & $0.65 \times 0.65$ & $0.9 \times 0.9$ & $0.9 \times 0.9$ \\
Rectangular & $0.65 \times 0.65$ & 0.95 & 0.9 \\
\hline
\end{tabular}


of structure loading on foundation and for different failure model of soils. Modulus of elasticity of pile material is taken as $2.35 \times 107 \mathrm{kN} / \mathrm{m}^{2}$ while its density is considered as $25 \mathrm{kN} / \mathrm{m}^{3}$. The soil profile is of two layer systems with upper layer of loose sand and lower layer of dense sand (stiff soil). The different thickness of stiff soil is considered in the model to study the effect of stiff soil on the interaction analysis. Three thickness proportion of stiff soil namely $25 \%, 50 \%$ and $75 \%$ of total thickness are taken. The water level is assumed at the ground surface.

\section{Soil Models}

Soil is a complex material that behaves differently in primary loading, unloading and reloading. It exhibits nonlinear behaviour well below failure condition with stress dependant stiffness [17]. The elastic-perfectly plastic models based on soil failure criteria namely, Mohr-coulomb (MC) and Mohr-coulomb incremental stiffness (MCI) with depth, are taken because of the most common used models. In the study, second order Hardening Soil (HS) model that considers shear hardening and compression hardening [17] and suitable to cohesion less soil is also used. The assigned soil parameters for the two layers soil field are given in Table 2.

\section{Finite Element Modelling Methodology}

The finite element method based on software PLAXIS 3D is used for three dimensional modelling of 15-storey building structure having piled-raft foundation in layered soil field. The columns and piles are modelled as frame elements with linear elastic properties. The interaction effect of pile and soil at the pile shaft is considered by means of Elasto-Plastic line-to-volume and point-to-volume interfaces [19] as an embedded pile model. The embedded pile model consisting of beam elements with non-linear skin and tip interfaces. There is no need for mesh refinement around piles as 3D mesh is not distorted by introducing embedded pile model [19]. The floor slab and raft is discretized using 6-node triangular plate elements with linear elastic properties. The soil field with two layers of non-cohesive soils namely loose and dense sand is modelled as 15-node wedge triangular continuum elements. The total number of elements in the discretized mesh for square building structure including soil field are 35,785 while for rectangular building structure including soil field, number of elements are 24,785. As the mesh discretization has no significant effect on piled-raft analysis result [20], mesh sensitivity has not been examined and mesh generated automatically by PLAXIS code is used for the analysis. The 3D finite elements structural models of square (aspect ratio $=1$ ) and rectangular (aspect ratio $=1.75$ ) shaped buildings with piled-raft foundation are shown in Figure 2. The cross-section of 3D finite elements soil field models are shown in Figure 3.

Table 2. Soil parameters for different soil models.

\begin{tabular}{|c|c|c|c|}
\hline \multirow{2}{*}{ Parameters } & \multirow{2}{*}{ Soil model } & \multicolumn{2}{|c|}{ Soil layer } \\
\hline & & Loose sand & Dense sand \\
\hline Unsaturated weight $\left(\gamma_{\text {unsat }}\right), \mathrm{kN} / \mathrm{m}^{3}$ & All models & 17 & 19 \\
\hline Saturated weight $\left(\gamma_{\text {sat }}\right)$ & All models & 20 & 21 \\
\hline Stiffness $\left(E_{50}^{r e f}\right), \mathrm{kN} / \mathrm{m}^{2}$ & HS [9] & 20,000 & 60,000 \\
\hline Stiffness $\left(E_{\text {oed }}^{\text {ref }}\right), \mathrm{kN} / \mathrm{m}^{2}$ & HS [9] & 20,000 & 60,000 \\
\hline Stiffness ( $\left.E_{u r}^{r e f}\right), \mathrm{kN} / \mathrm{m}^{2}$ & All models & 100,000 & 180,000 \\
\hline Rate of increase of $E$ with depth $(\Delta E) \mathrm{kN} / \mathrm{m}^{2}$ & MCI [18] & 4720 & 31,470 \\
\hline Power $(m)$ & HS & 0.65 & 0.55 \\
\hline Poisson's ratio $(v)$ & All models & 0.2 & 0.2 \\
\hline Dilatancy $(\psi)$, degree & All models & 2 & 8 \\
\hline Friction angle $(\varphi)$, degree & All models & 32 & 38 \\
\hline Cohesion $\left(c_{\mathrm{ref}}\right), \mathrm{kN} / \mathrm{m}^{2}$ & HS & 0.1 & 0.1 \\
\hline
\end{tabular}



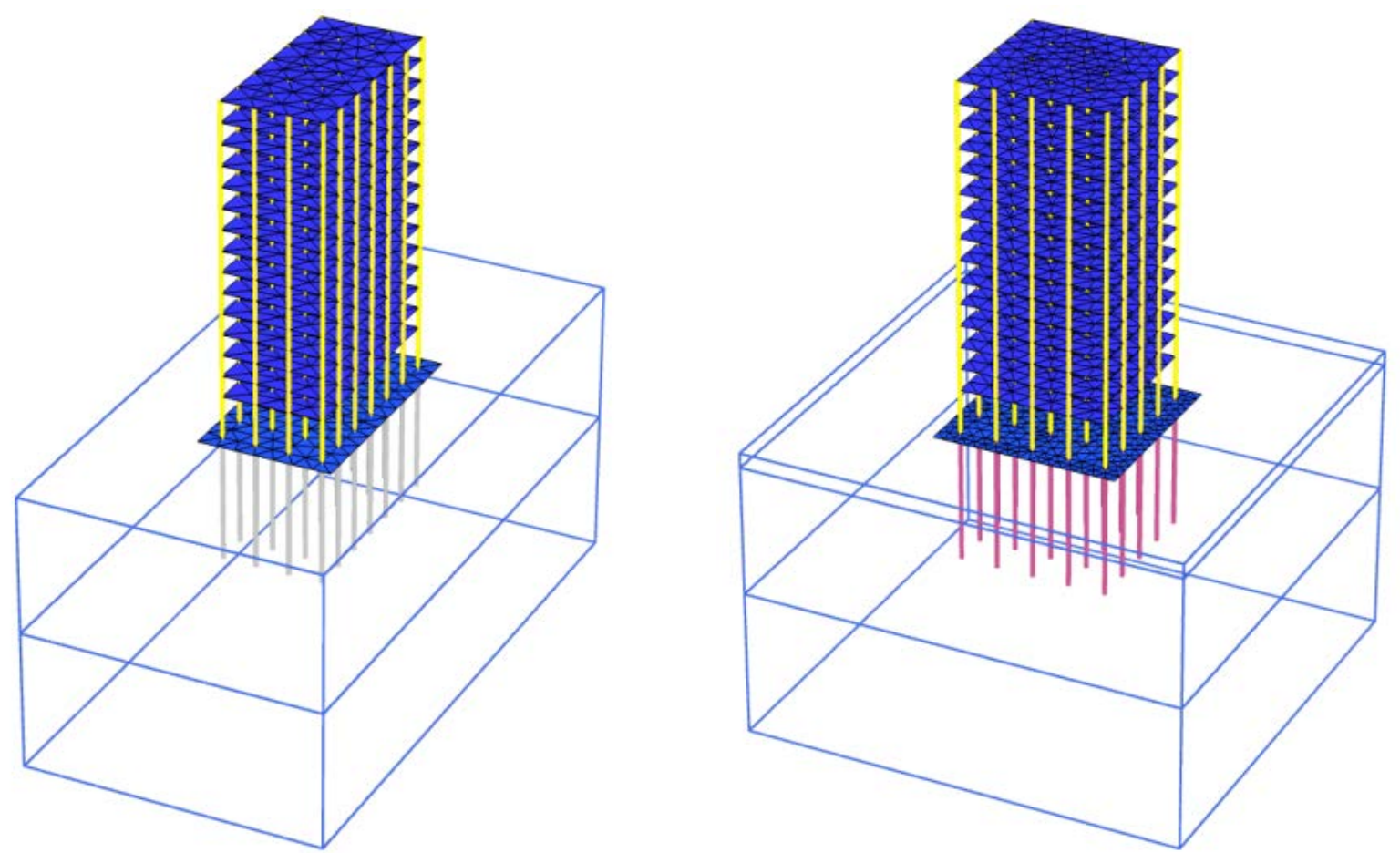

Figure 2. 3D model of buildings with piled-raft foundation.
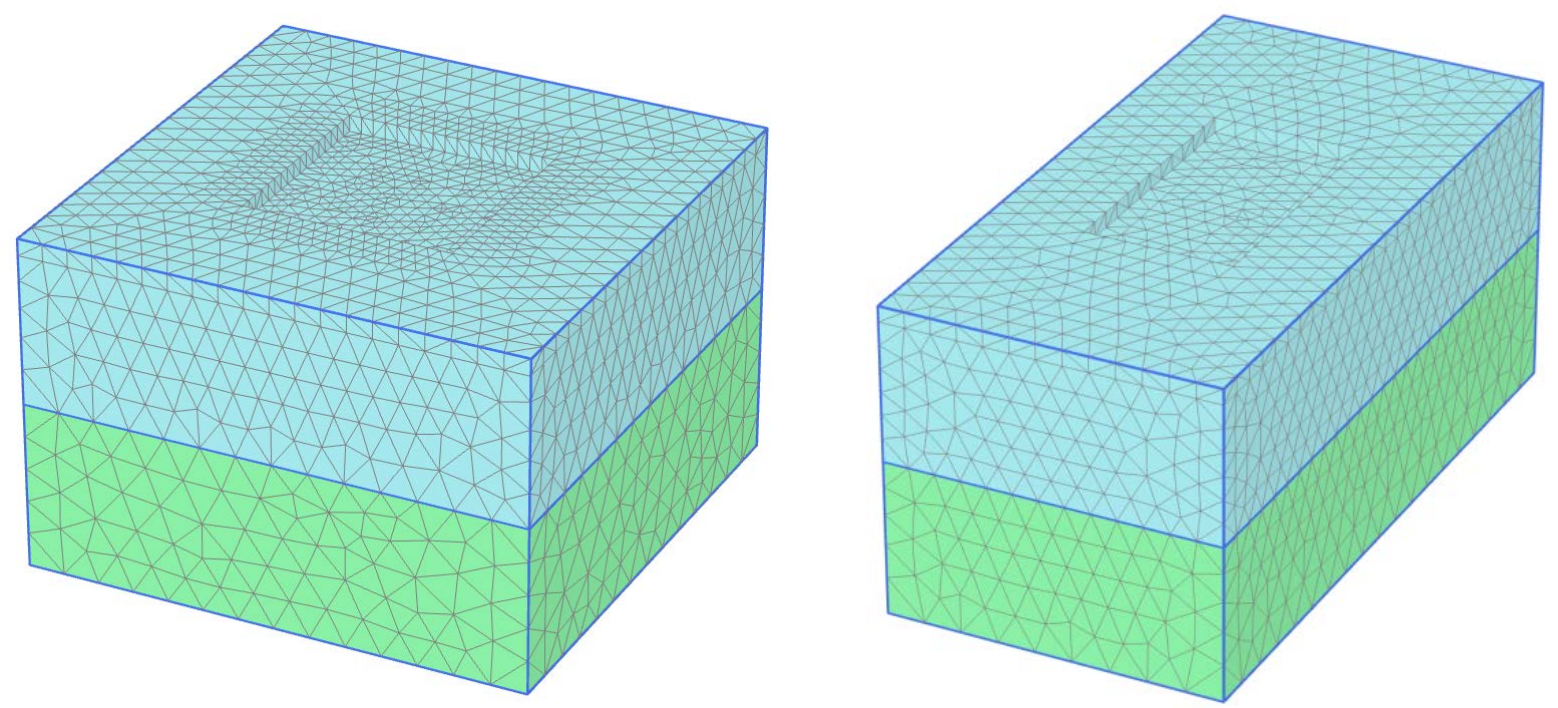

Figure 3. 3D finite elements foundation soil models of square and rectangular shaped buildings.

\section{Results and Discussion}

\subsection{Foundation-Structure Interaction Effect on Soil Field}

The results of interaction of building foundation-structure with different aspect ratio of building and different soil models on the soil are given in Table 3. The results are presented at three locations below the ground level, i.e. $2 \mathrm{~m}$ (below raft level), $10 \mathrm{~m}$ and $20 \mathrm{~m}$ below the ground. It is evident from the results that there is noteworthy effect of interaction of building aspect ratio and soil failure models on the soil response. The predicted amount of soil settlement is different with different aspect ratio of building. The soil settlement decreases with 
Table 3. Maximum soil settlement with different soil models and building aspect ratio.

\begin{tabular}{|c|c|c|c|}
\hline Soil Models & \multicolumn{2}{|c|}{ Location } & Maximum Soil Settlement (cm) \\
\hline \multirow{6}{*}{$\begin{array}{c}\text { Hardening Model } \\
\text { (Aspect Ratio }=1.0 \& 1.75 \text { ) }\end{array}$} & \multirow{2}{*}{ Below the raft, 2 m below GL } & Aspect Ratio $=1.0$ & 23.19 \\
\hline & & Aspect Ratio $=1.75$ & 22.0 \\
\hline & \multirow{2}{*}{10 m below GL } & Aspect Ratio $=1.0$ & 11.74 \\
\hline & & Aspect Ratio $=1.75$ & 11.30 \\
\hline & \multirow{2}{*}{ Below the pile, $20 \mathrm{~m}$ below GL } & Aspect Ratio $=1.0$ & 3.22 \\
\hline & & Aspect Ratio $=1.75$ & 3.05 \\
\hline \multirow{3}{*}{$\begin{array}{l}\text { Mohr-Coulomb Incremental } \\
\text { Model } \\
\quad(\text { Aspect Ratio = 1.0) }\end{array}$} & \multicolumn{2}{|c|}{ Below the raft, $2 \mathrm{~m}$ below GL } & 26.83 \\
\hline & \multicolumn{2}{|c|}{$10 \mathrm{~m}$ below GL } & 14.37 \\
\hline & \multicolumn{2}{|c|}{ Below the pile, $20 \mathrm{~m}$ below GL } & 4.16 \\
\hline \multirow{3}{*}{$\begin{array}{l}\text { Mohr-Coulomb Incremental } \\
\text { Model } \\
\quad(\text { Aspect Ratio }=1.0)\end{array}$} & \multicolumn{2}{|c|}{ Below the raft, $2 \mathrm{~m}$ below GL } & 12.97 \\
\hline & \multicolumn{2}{|c|}{$10 \mathrm{~m}$ below $\mathrm{GL}$} & 4.43 \\
\hline & \multicolumn{2}{|c|}{ Below the pile, 20 m below GL } & 1.23 \\
\hline
\end{tabular}

the increase of aspect ratio of building. This may due to the reason that the load is distributed on a larger area in one direction of the building. The use of different soil failure model for soil field has also predicted dissimilar soil settlement. The behavior of soil at various levels also varies under different failure models of soil. The soil settlement is predicted highest using Mohr-coulomb failure criteria (MC) and predicted least by Mohr-coulomb incremental stiffness model $(\mathrm{MCI})$. The soil settlements of a square building (aspect ratio $=1$ ) at raft level are $26.83 \mathrm{~cm}, 12.97 \mathrm{~cm}$ and $23.19 \mathrm{~cm}$ respectively in Mohr-coulomb (MC) model, Mohr-coulomb incremental stiffness (MCI) model and hardening soil (HS) model while, the settlements at pile end are $4.16 \mathrm{~cm}, 1.23 \mathrm{~cm}$ and $3.22 \mathrm{~cm}$. For the rectangular structure (aspect ratio $=1.75$ ), the soil settlement is concentrated in the shorter direction of the building structure. The contours of soil settlements along vertical cross-section of the soil field for building aspect ratios and soil failure criteria are depicted in Figure 4 and Figure 5.

Table 4 presents the soil settlements variation with proportional depth of loose sand layer of the building foundation soil. The contours of soil settlements along vertical and horizontal cross-section of the soil field are shown in Figure 6. It is evident from the results that the maximum soil settlements go on increasing with the increase of depth of loose sand layer below the ground level. The soil settlements are also increases with the increase of loose sand layer at same level below the ground level. The maximum soil settlements with different proportional depth of loose sand layer are $18.46 \mathrm{~cm}, 23.19 \mathrm{~cm}$ and $23.95 \mathrm{~cm}$ respectively at loose sand depth $25 \%, 50 \%$ and $75 \%$ of total depth, while with similar proportional depth of loose sand layer, the settlements at bottom pile end are $2.76 \mathrm{~cm}, 3.22 \mathrm{~cm}$ and $6.0 \mathrm{~cm}$. For different proportional depth of loose sand layer, settlement dissipates along the raft sides towards the outer edges of soil field. The change in soil settlement is observed with lesser stiff layer thickness up to the pile length and more thickness of lesser stiff layer will not affect the soil behavior in piled-raft foundation.

Table 5 shows the predicted soil settlements with the mode of super structure loading to the foundation soil. The contours of soil settlements along the vertical and horizontal cross-section of the soil field are shown in Figure 7. It is evident from the results that there is clear interaction of building structure with the foundation soil. The analysis of piled-raft foundation-soil models with super structure will indicate foundation soil to be more rigid than model without the super structure. The maximum soil settlements will decreases when loading is applied through the construction phasing of the building structure or sequential loading. The maximum soil settlements will increase when loading is applied through the vertical elements tributary area method of the structure. The maximum soil settlements are $23.19 \mathrm{~cm} 23.45 \mathrm{~cm}$ and $22.74 \mathrm{~cm}$ respectively at loading through the super structure, loading directly to footing and through sequential loading while on similar conditions of loading, the soil settlements at bottom pile end are $3.22 \mathrm{~cm}, 3.25 \mathrm{~cm}$, and $3.16 \mathrm{~cm}$. 


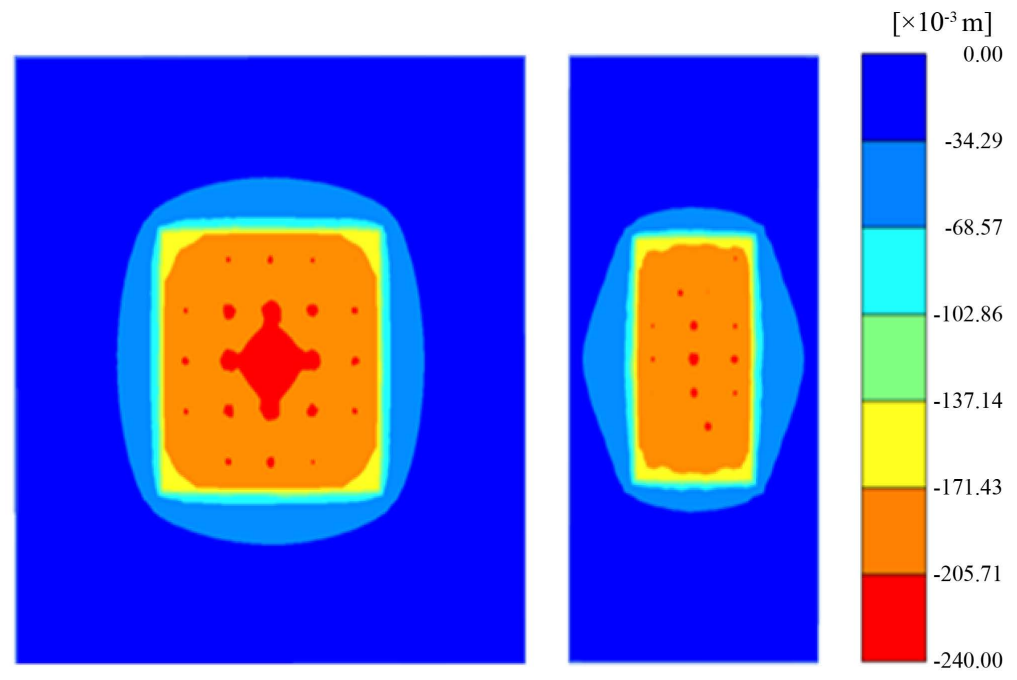

Horizontal Sections at $2.0 \mathrm{~m}$ below GL (Below Raft Level)

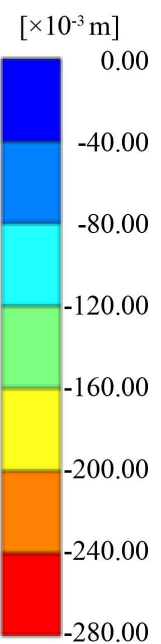

Vertical Sections along the shorter direction

Figure 4. Contours of soil settlements on horizontal and vertical section of square (aspect ratio $=1.0)$ and rectangular buildings (aspect ratio $=1.75)$.

Table 4. Maximum soil settlement of square structure building with loose sand layer (HS) proportional depth.

\begin{tabular}{lcc}
\hline \multicolumn{1}{c}{ Soil Models } & \multicolumn{1}{c}{ Location } & Maximum Soil Settlement (cm) \\
\hline Top Loose Sand-25\% of total depth & Below the raft, $2 \mathrm{~m}$ below GL & 18.46 \\
& $10 \mathrm{~m}$ below GL & 2.49 \\
& Below the pile, $20 \mathrm{~m}$ below GL & 23.19 \\
Top Loose Sand- $-50 \%$ of total depth & Below the raft, $2 \mathrm{~m}$ below GL & 11.74 \\
& $10 \mathrm{~m}$ below GL & 3.22 \\
Top Loose Sand- $-75 \%$ of total depth & Below the pile, $20 \mathrm{~m}$ below GL & 23.95 \\
\hline
\end{tabular}



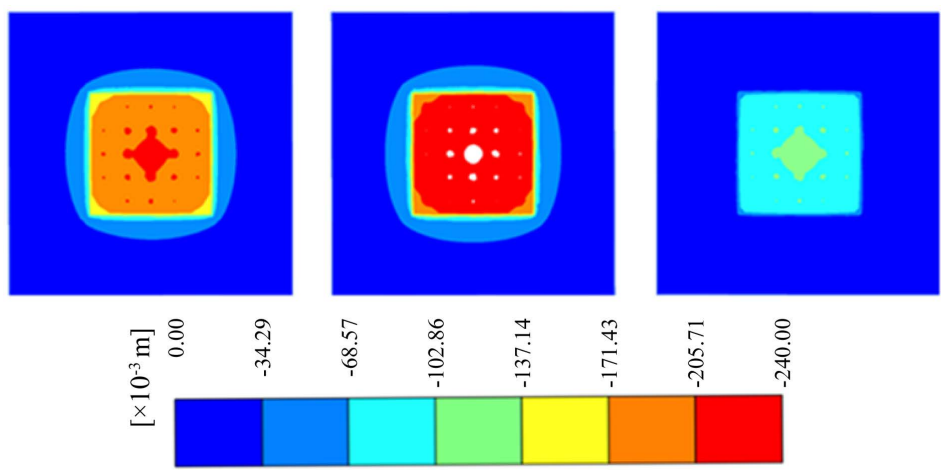

$2.0 \mathrm{~m}$ below $\mathrm{GL}$
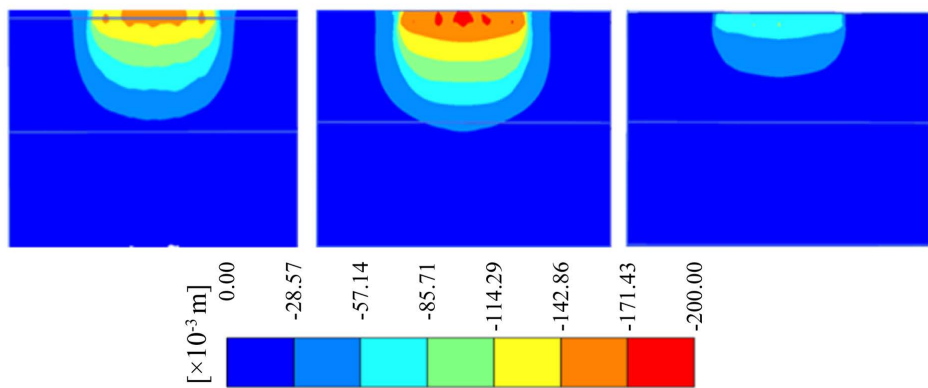

(a) Hardening Soil

(b) Mohr-coulomb (MC)

(c) MC Incremental

Vertical Sections

Figure 5. Contours of soil settlements on horizontal and vertical section of square buildings with soil models.
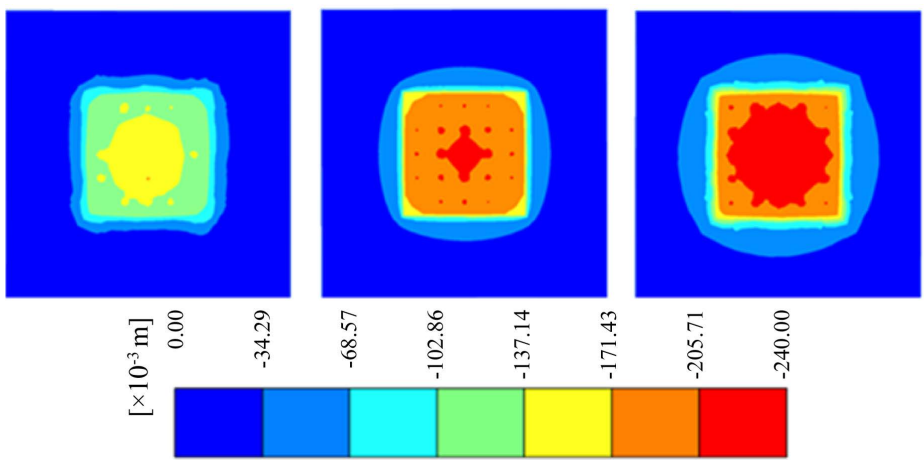

$2.0 \mathrm{~m}$ below GL
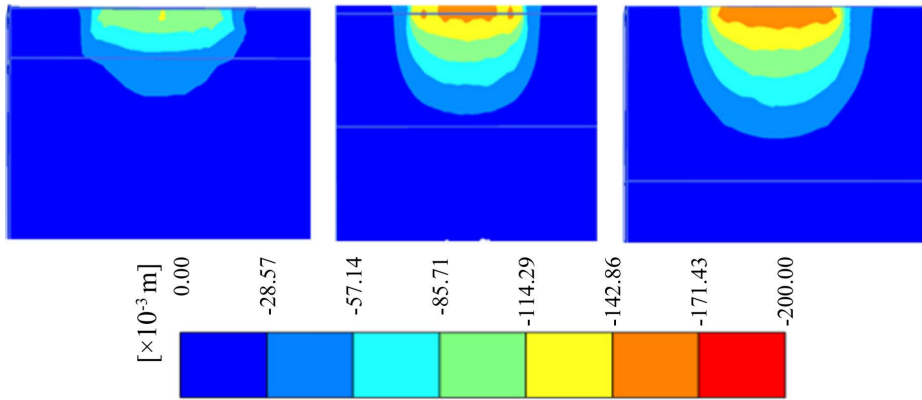

(a) 25\% Loose Sand

(b) $50 \%$ Loose Sand

(c) $75 \%$ Loose Sand

Figure 6. Contours of soil settlements on horizontal and vertical section of square buildings with proportional depth of loose sand (HS) layer. 

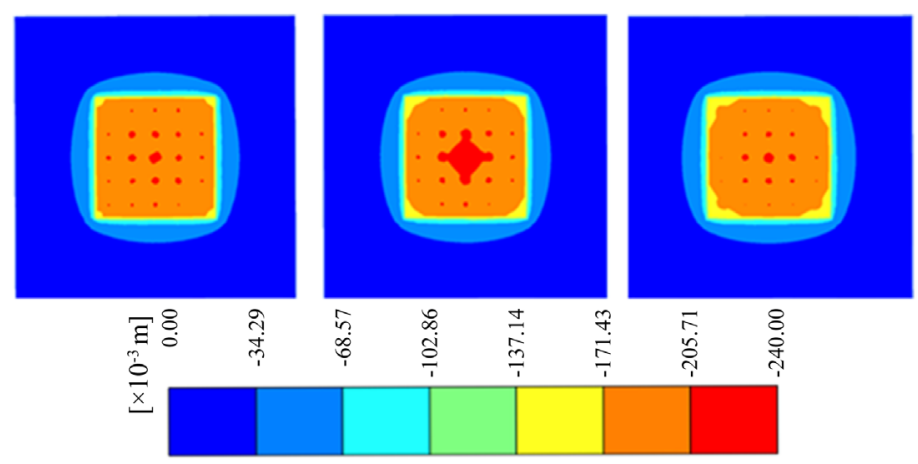

$2.0 \mathrm{~m}$ below GL
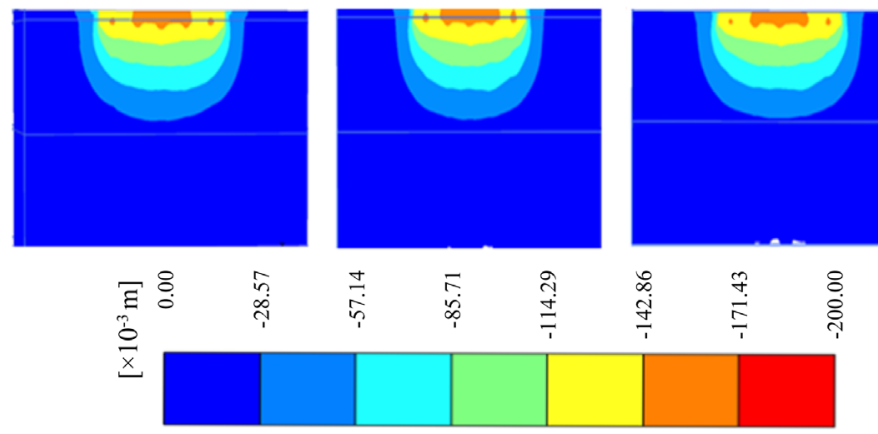

(a) With super-structure

(b) Without super-structure

(c) Sequential

Vertical Sections

Figure 7. Contours of soil settlements on horizontal and vertical section of squarebuildings with mode of super structure loading.

Table 5. Maximum soil settlement of square structure building with mode of super structure loading.

\begin{tabular}{|ccc|}
\hline \multicolumn{1}{c}{ Soil Models } & Location & Maximum Soil Settlement (cm) \\
\hline Loading through super structure & Below the raft, $2 \mathrm{~m}$ below GL & 23.19 \\
& $10 \mathrm{~m}$ below GL & 11.74 \\
Loading without super structure & Below the pile, $20 \mathrm{~m}$ below GL & 23.45 \\
& Below the raft, 2 m below GL & 11.6 \\
Sequential loading through super structure & $10 \mathrm{~m}$ below GL & 3.25 \\
\hline
\end{tabular}

\subsection{Foundation-Structure Interaction Effect on Piled-Raft Footing}

Table 6 shows the analysis results of interaction of building foundation-structure on the component of piled-raft footing. The table shows the computed settlements of raft and total static load transferred from the upper structure to the raft of building with different aspect ratios and soil failure models. The forces developed in the raft are also presented in this table. The results of analysis depicts that the amount of raft maximum and differential settlement vary with different aspect ratio of buildings and failure models of soil. The differential settlement and raft forces decrease with the increase of aspect ratio of the building structure. The predicted differential settlement of the raft is highest using Mohr-coulomb failure criteria of soil field and it is least in Mohr-coulomb incremental stiffness model. The least value of maximum positive and negative moment in the raft is computed 
Table 6. Differential settlement, moments and forces in the raft with different soil models and building structure aspect ratio.

\begin{tabular}{|c|c|c|c|c|}
\hline \multirow[b]{2}{*}{ Building Aspect Ratio } & \multirow{2}{*}{$\begin{array}{l}\text { Settlements/Max. Moments/Max. } \\
\text { Shear Force/Vertical Load }\end{array}$} & \multicolumn{3}{|c|}{ Soil Models } \\
\hline & & Hardening Model & $\begin{array}{l}\text { Mohr Coulomb (MC) } \\
\text { Model }\end{array}$ & $\begin{array}{l}\text { MC Incremental } \\
\text { Model }\end{array}$ \\
\hline \multirow{5}{*}{$\begin{array}{l}\text { Aspect Ratio }=1.0 \\
\text { (Square) }\end{array}$} & Differential Settlement $(\mathrm{cm})$ & 7.3 & 7.8 & 6.37 \\
\hline & Positive Moment $(\mathrm{kN} \cdot \mathrm{m} / \mathrm{m})$ & 4850 & 5092 & 4455 \\
\hline & Negative Moment $(\mathrm{kN} \cdot \mathrm{m} / \mathrm{m})$ & 130 & 121 & 120 \\
\hline & Shear Force (kN) & 4852 & 4986 & 4916 \\
\hline & Total Vertical Load (kN) & 138,801 & 138,801 & 137,014 \\
\hline \multirow{5}{*}{$\begin{array}{l}\text { Aspect Ratio }=1.75 \\
\quad \text { (Rectangular) }\end{array}$} & Differential Settlement $(\mathrm{cm})$ & 6 & & \\
\hline & Positive Moment $(\mathrm{kN} \cdot \mathrm{m} / \mathrm{m})$ & 2562 & & \\
\hline & Negative Moment $(\mathrm{kN} \cdot \mathrm{m} / \mathrm{m})$ & 213 & & \\
\hline & Shear Force $(\mathrm{kN})$ & 1401 & & \\
\hline & Total Vertical Load (kN) & 138,812 & & \\
\hline
\end{tabular}

with Mohr-coulomb incremental stiffness (MCI) failure criteria. The computed value of raft maximum positive moments are $(4850,5092,4455 \mathrm{kN} \cdot \mathrm{m} / \mathrm{m})$, raft maximum negative moments are $(130,121,120 \mathrm{kN} \cdot \mathrm{m} / \mathrm{m})$, and raft maximum shear force are (4852, 4986, $4916 \mathrm{kN}$ ) using hardening soil (HS) model, Mohr-coulomb (MC) model and Mohr-coulomb incremental stiffness (MCI) model respectively. The maximum positive moment, maximum negative moment and maximum shear force in the raft obtained from the interaction analysis are 2563 $\mathrm{kN} \cdot \mathrm{m} / \mathrm{m}, 213 \mathrm{kN} \cdot \mathrm{m} / \mathrm{m}$ and $1401 \mathrm{kN}$ respectively for building aspect ratio of 1.75 .

Table 7 and Table 8 show the differential settlement and forces developed in the raft with proportional depth of loose sand and mode of loading to the foundation soil. The results of analysis concluded that the amount of raft maximum and differential settlement varies with different proportional depth of loose sand and mode of loading to the foundation soil. The differential settlement of the raft decreases with the increase of proportional depth of loose sand. The raft forces decreases with the increase of aspect ratio of the building structure. The predicted differential settlement of the raft is highest using Mohr-coulomb failure criteria of soil field and it is least in Mohr-coulomb incremental stiffness model. The lowest value of maximum negative moment in the raft is computed with lower thickness of loose sand layer while the lowest value of maximum shear in the raft is obtained with highest thickness of loose sand layer. The computed value of raft maximum positive moments are $(5129,4850,4809 \mathrm{kN} \cdot \mathrm{m} / \mathrm{m})$, raft maximum negative moments are $(117,130,129 \mathrm{kN} \cdot \mathrm{m} / \mathrm{m})$, and raft maximum shear force are $(2390,4852,2295 \mathrm{kN})$ using $25 \%, 50 \%$ and $75 \%$ proportional thickness of loose sand layer respectively.

The analysis results of piled-raft foundation model, developed without the superstructure and loading directly to structure based on tributary area of columns and loading through super-structure with or without phasing of construction, is shown in the Table 8. The results of piled-raft foundation model with and without the superstructure indicate a clear interaction between the foundation-soil and the super structure. The bending moments and shear force due to loading and differential settlements in the raft are lesser in case of piled-raft foundation-soil model without the building super structure. The developed raft bending moments is maximum when is loading is transferred to footing is sequential manner. There is no noticeable interaction effect on differential settlements of the raft with different mode of application of loading to the foundation. The maximum and differential settlements of soil field due to piled-raft foundation with different mode of loading to foundation are $(23.19 \mathrm{~cm}, 7.3 \mathrm{~cm})$ and $(23.45 \mathrm{~cm}, 6.76 \mathrm{~cm}),(22.74 \mathrm{~cm}, 7.32 \mathrm{~cm})$ respectively due to loading through building super structure, loading directly to footing and due to sequential loading of the super structure. The maximum positive moments and negative moments, and maximum shear force in the raft are $(4850 \mathrm{kN} \cdot \mathrm{m} / \mathrm{m}, 130 \mathrm{kN} \cdot \mathrm{m} / \mathrm{m}$, $4852 \mathrm{kN}),(3916 \mathrm{kN} \cdot \mathrm{m} / \mathrm{m}, 170 \mathrm{kN} \cdot \mathrm{m} / \mathrm{m}, 3626 \mathrm{kN})$ and $(4850 \mathrm{kN} \cdot \mathrm{m} / \mathrm{m}, 131 \mathrm{kN} \cdot \mathrm{m} / \mathrm{m}, 4992 \mathrm{kN})$ respectively due to loading through building super structure, loading directly to piled-raft footing and due to sequential loading of 
Table 7. Settlement, moments and forces in the raft with proportional depth of loose sand (HS) layer.

\begin{tabular}{cccc}
\hline \multirow{2}{*}{\begin{tabular}{c} 
Settlements/Max. Moments/Max. Shear Force/Vertical Load \\
\cline { 2 - 4 }
\end{tabular}} & \multicolumn{2}{c}{ Proportional Depth of Loose Sand (HS) Layer } \\
\hline Differential Settlement $(\mathrm{cm})$ & 9.26 & 7.3 & 7.26 \\
\hline Positive Moment $(\mathrm{kN} \cdot \mathrm{m} / \mathrm{m})$ & 5129 & 4850 & 4809 \\
\hline Negative Moment $(\mathrm{kN} \cdot \mathrm{m} / \mathrm{m})$ & 117 & 130 & 129 \\
\hline Shear Force $(\mathrm{kN})$ & 2390 & 4852 & 2295 \\
\hline Total Vertical Load $(\mathrm{kN})$ & 138,759 & 138,801 & 138,767 \\
\hline
\end{tabular}

Table 8. Settlement, moments and forces in the raft with mode of super structure loading.

\begin{tabular}{cccc}
\hline \multirow{2}{*}{$\begin{array}{c}\text { Settlements/Max. Moments/Max. Shear } \\
\text { Force/Vertical Load }\end{array}$} & \multicolumn{3}{c}{ Mode of Super Structure Loading } \\
\cline { 2 - 4 } & $\begin{array}{c}\text { Single Phase } \\
\text { Super-Structure Loading }\end{array}$ & $\begin{array}{c}\text { Without Super-Structure-Direct } \\
\text { Loading }\end{array}$ & Sequential Loading \\
\hline Maximum Settlement $(\mathrm{cm})$ & 23.19 & 23.45 & 22.74 \\
Differential Settlement $(\mathrm{cm})$ & 7.3 & 6.76 & 7.32 \\
Positive Moment $(\mathrm{kN} \cdot \mathrm{m} / \mathrm{m})$ & 4850 & 3916 & 4856 \\
Negative Moment $(\mathrm{kN} \cdot \mathrm{m} / \mathrm{m})$ & 130 & 170 & 131 \\
Shear Force $(\mathrm{kN})$ & 4852 & 3626 & 4992 \\
Total Vertical Load $(\mathrm{kN})$ & 138,801 & 138,808 & 138,804 \\
\hline
\end{tabular}

the super structure.

\subsection{Foundation-Structure Interaction Effect on Super-Structure}

Table 9 and Table 10 show the results of interaction of building foundation-structure on the component of super-structure (i.e. columns and slabs) due to phasing of construction. The side sways (deflections) and axial loads in the columns are given in Table 9. The axial loads in columns of building are affected by the different mode of loading applied to the foundation soil. The maximum axial loading in the column increases while minimum axial loading decreases due to application of loading in sequential way. The maximum side sway or deflection of the column is increased when applied loading considers the construction phasing. The maximum top side sway in $\mathrm{x}$ and $\mathrm{y}$ directions for sequential loading to the building structure are $95 \mathrm{~mm}$ and $207 \mathrm{~mm}$ while deflections for one phase loading to the foundation are $12.2 \mathrm{~mm}$ and 43.3 . The interaction of the super structure with the raft-foundation-soil will affect the maximum and minimum axial load of the columns. The maximum and minimum axial loads of the columns, obtained by incorporating the super-structure mode of loading to piledraft foundation-soil model, are (9938 kN, $1768 \mathrm{kN})$ and $(10,244 \mathrm{kN}, 1740 \mathrm{kN})$ for one phase loading and for sequential loading to the building structure respectively while based on the column tributary area, the maximum and minimum axial load of the columns are $7556 \mathrm{kN}$ and $2268 \mathrm{kN}$.

Table 10 depicts the maximum deflections and moments in slab at first, eighth floor and roof of the super structure with sequential loading to the foundation. The floor slab deflections and slab forces are different with different mode of loading of the building super structure. There is clear interaction effect on different floor of the building with phase loading of construction. The maximum deflection of the first floor slab is observed highest due to loading of super structure applied in sequential manner but observed decreasing on upper floors of building structure while deflection observed is more or less same if super structure loading is applied in single phase. The maximum deflection produced in the floor slabs of roof, eighth and first floor of the building super structure with different mode of loading to the foundation are $(38.6 \mathrm{~cm}, 37.5 \mathrm{~cm}, 34.6 \mathrm{~cm})$ and $(16.1 \mathrm{~cm}, 24.0$ $\mathrm{cm}, 38.8 \mathrm{~cm}$ ) respectively due to loading in one phase through building super structure and due to sequential loading of the super structure. The moments developed in the roof slab are observed more after application of sequential loading of super structure than the other floor slabs and go on increasing on others floors of building structure. The maximum positive moments and negative moments in the roof slab, eighth and first floor of the 
Table 9. Columns deflection and axial loads with mode of super structure loading.

\begin{tabular}{cccc}
\hline \multirow{2}{*}{ Top Deflection (mm)/Axial Load (kN) } & \multicolumn{3}{c}{ Mode of Super Structure Loading } \\
\cline { 2 - 4 } Top Deflection (x-dir.) & Super-Structure Loading & Sequential Loading & Without Super-Structure Model \\
\hline Top Deflection (y-dir.) & 23.19 & 23.45 & 22.74 \\
Axial Load (max.) & 7.3 & 6.76 & 7.32 \\
Axial Load (min.) & 4850 & 3916 & 4856 \\
\hline
\end{tabular}

Table 10. Maximum deflection and moments in the floors of square building structure with different mode of super structure loading.

\begin{tabular}{cccc}
\hline \multirow{2}{*}{ Storey Level } & Max. Slab Deflection/Max. Moments & \multicolumn{2}{c}{ Mode of Super Structure Loading } \\
\cline { 2 - 3 } & Deflection $(\mathrm{mm})$ & Single Phase Super-Structure Loading & Sequential Loading \\
\hline \multirow{2}{*}{ First Floor } & Positive Moment $(\mathrm{kN} \cdot \mathrm{m} / \mathrm{m})$ & 64.6 & 38.8 \\
& Negative Moment $(\mathrm{kN} \cdot \mathrm{m} / \mathrm{m})$ & 97 & 64 \\
\multirow{2}{*}{ Eighth Floor } & Deflection $(\mathrm{mm})$ & 37.5 & 97 \\
& Positive Moment $(\mathrm{kN} \cdot \mathrm{m} / \mathrm{m})$ & 65 & 63 \\
& Negative Moment $(\mathrm{kN} \cdot \mathrm{m} / \mathrm{m})$ & 95 & 100 \\
Roof & Deflection $(\mathrm{mm})$ & 38.6 & 16.1 \\
& Positive Moment $(\mathrm{kN} \cdot \mathrm{m} / \mathrm{m})$ & 66 & 61 \\
\hline
\end{tabular}

building are respectively $(66 \mathrm{kN} \cdot \mathrm{m} / \mathrm{m}, 94 \mathrm{kN} \cdot \mathrm{m} / \mathrm{m}),(65 \mathrm{kN} \cdot \mathrm{m} / \mathrm{m}, 95 \mathrm{kN} \cdot \mathrm{m} / \mathrm{m})$ and $(64 \mathrm{kN} \cdot \mathrm{m} / \mathrm{m}, 97 \mathrm{kN} \cdot \mathrm{m} / \mathrm{m})$ due to loading through building super structure and while these forces respectively are $(61 \mathrm{kN} \cdot \mathrm{m} / \mathrm{m}, 106 \mathrm{kN} \cdot \mathrm{m} / \mathrm{m})$, $(63 \mathrm{kN} \cdot \mathrm{m} / \mathrm{m}, 100 \mathrm{kN} \cdot \mathrm{m} / \mathrm{m})$ and $(64 \mathrm{kN} \cdot \mathrm{m} / \mathrm{m}, 97 \mathrm{kN} \cdot \mathrm{m} / \mathrm{m})$ due to sequential loading of the super structure.

\section{Conclusions}

The analysis of combined piled-raft foundation of multi-storey building is very challenging because of complexities involved in the interaction between the components of building structure and soil field. The analysis of the tall building structure with complex foundation system in non-uniform (layered soil) soil field should include the interaction of structure-foundation-soil. In this study, the finite element 3D interaction analysis of building structure having piled-raft foundation in two layered non-cohesive soil field is carried out using PLAXIS 3D foundation code. The complete interaction among the soil field depth, soil layer type with foundation and foundation with super-structure with different aspect ratio and loading mode has been evaluated. The available literatures on soil-piled-raft foundation analysis are based on direct loading of superstructure on raft and without considering interaction of superstructure and foundation. The foundation soil in piled-raft foundation-soil models without including super structure will be stiffer than models with the one-phase super structure loading or sequential super structure loading.

The foundation structure and soil field response is significantly affected by different building structure shape and soil failure models. The foundation soil settlement and raft differential settlement is highest using Mohrcoulomb (MC) failure criteria of soil field among the HS, MC and MCI failure criteria. The soil field response in layered soil is also affected by presence of lesser stiff layer below the raft. The soil behavior in piled-raft foundation is not much affected by lesser stiff layer having thickness more than the pile length. A clear foundationstructure interaction effect is observed on the building superstructure components behavior with application of construction loading sequentially. The wide variability of deflection and moments of the floor slab is also observed due to loading of super structure applied in sequential manner which is not observed when super structure loading is applied as a single phase. The deflection and moments of the first floor slab is observed highest due to 
loading of super structure applied in sequential manner but observed decreasing on upper floors of building structure.

\section{References}

[1] Bobet, A. (2010) Numerical Methods in Geo-Mechanics. The Arabian Journal for Science and Engineering, 35, 2748.

[2] Hemsley, J.A. (2000) Design Applications of Raft Foundations. Thomas Telford Ltd., London.

[3] Ahmed, M., Mahmoud, H. and Mallick, J. (2013) Advances in Piled-Raft Foundation System. Recent Trends in Civil Engineering and Technology, 3, 1-8.

[4] Lin, D.G. and Feng, Z.Y. (2006) A Numerical Study of Piled Raft Foundations. Journal of the Chinese Institute of Engineers, 29, 1091-1097. http://dx.doi.org/10.1080/02533839.2006.9671208

[5] Rabiei, M. (2010) Piled Raft Design for High Rise Building. Electronic Journal of Geotechnical Engineering, 15, 495505.

[6] Singh, N.T. and Singh, B. (2008) Interaction Analysis for Piled Rafts in Cohesive Soils. 12th International Conference of International Association for Computer Methods and Advances in Geo-Mechanics (IACMAG), Goa, 1-6 October 2008, 3289-3296.

[7] Eslami, A., Veiskarami, M. and Eslami, M.M. (2012) Study on Optimized Piled-Raft Foundations (PRF) Performance with Connected and Non-Connected Piles-Three Case Histories. International Journal of Civil Engineering, 10, 100110.

[8] Kapackci, V. and Ozkan, M.Y. (2012) A Simplified Approach Applicable to the Settlement Estimation of Piled-Raft. ACTA Geo-Technica Slovenica, 1, 77-84.

[9] Nguyen, D.D.C., Jo, S.B. and Kim, D.S. (2013) Design Method of Piled-Raft Foundations under Vertical Load Considering Interaction Effects. Computers and Geotechnics, 47, 16-27. http://dx.doi.org/10.1016/j.compgeo.2012.06.007

[10] Horikoshi, K. and Randolph, M.F. (1998) A Contribution to Optimum Design of Piled Rafts. Geotechnique, 48, 301317. http://dx.doi.org/10.1680/geot.1998.48.3.301

[11] Cao, X.D., Wong, M.F. and Chang, M.F. (2004) Behavior of Model Rafts Resting on Pile-Reinforced Sand. Journal Geotechnical Engineering, 130, 129-138.

[12] Cooke, R.W. (1986) Piled Raft Foundations on Stiff Clays: A Contribution to Design Philosophy. Geotechnique, 36, 169-203. http://dx.doi.org/10.1680/geot.1986.36.2.169

[13] Prakoso, W.A. and Kulhawy, F.H. (2001) Contribution to Piled Raft Foundation Design. Journal Geotechnical Engineering, 127, 17-24.

[14] Mahmood, M.N. and Ahmed, S.Y. (2007) Nonlinear Dynamic Analysis of Framed Structures including Soil-Structure Interaction Effects. The Arabian Journal for Science and Engineering, 33, 45-64.

[15] Al-Shayea, N. and Zeedan, H. (2012) A New Approach for Estimating Thickness of Mat Foundations under Certain Conditions. The Arabian Journal for Science and Engineering, 37, 277-290. http://dx.doi.org/10.1007/s13369-012-0178-5

[16] PLAXIS Version 2012.02 (2012) Scientific Manual, Delft University of Technology \& PLAXIS, The Netherlands, A. A. Balkema, PUBLISHERS. http://www.plaxis.nl/

[17] Ti, K.S., Huat, B.B.K., Noorzaei, J., Jaafar, M.S. and Sew, G.S. (2009) A Review of Basic Soil Constitutive Models for Geotechnical Application. Electronic Journal Geotechnical Engineering, 14, 1-18.

[18] US Department of Transportation (2006) Federal Highway Administration. Publication No.: FHWA NHI-06-088.

[19] Engin, H.K. and Brinkgreve, R.B.J. (2009) Investigation of Pile Behavior Using Embedded Piles. Proceedings of the 17th International Conference on Soil Mechanics and Geotechnical Engineering. In: Hamza, M., et al., Eds., Alexandria, Millpress, Amsterdam.

[20] Lebeau, J.S. (2008) FE-Analysis of Piled and Piled Raft Foundations. Ph.D., Institute for Soil Mechanics and Foundation Engineering, Graz University of Technology, Graz. 
Scientific Research Publishing (SCIRP) is one of the largest Open Access journal publishers. It is currently publishing more than 200 open access, online, peer-reviewed journals covering a wide range of academic disciplines. SCIRP serves the worldwide academic communities and contributes to the progress and application of science with its publication.

Other selected journals from SCIRP are listed as below. Submit your manuscript to us via either submit@scirp.org or Online Submission Portal.
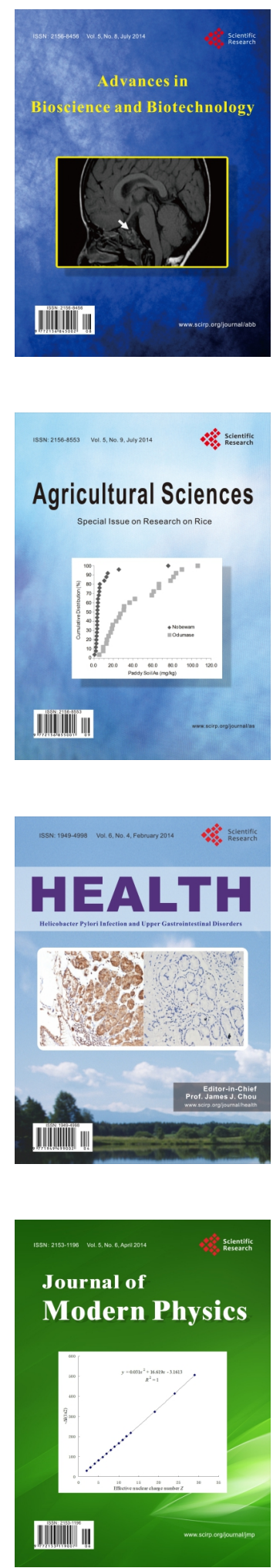
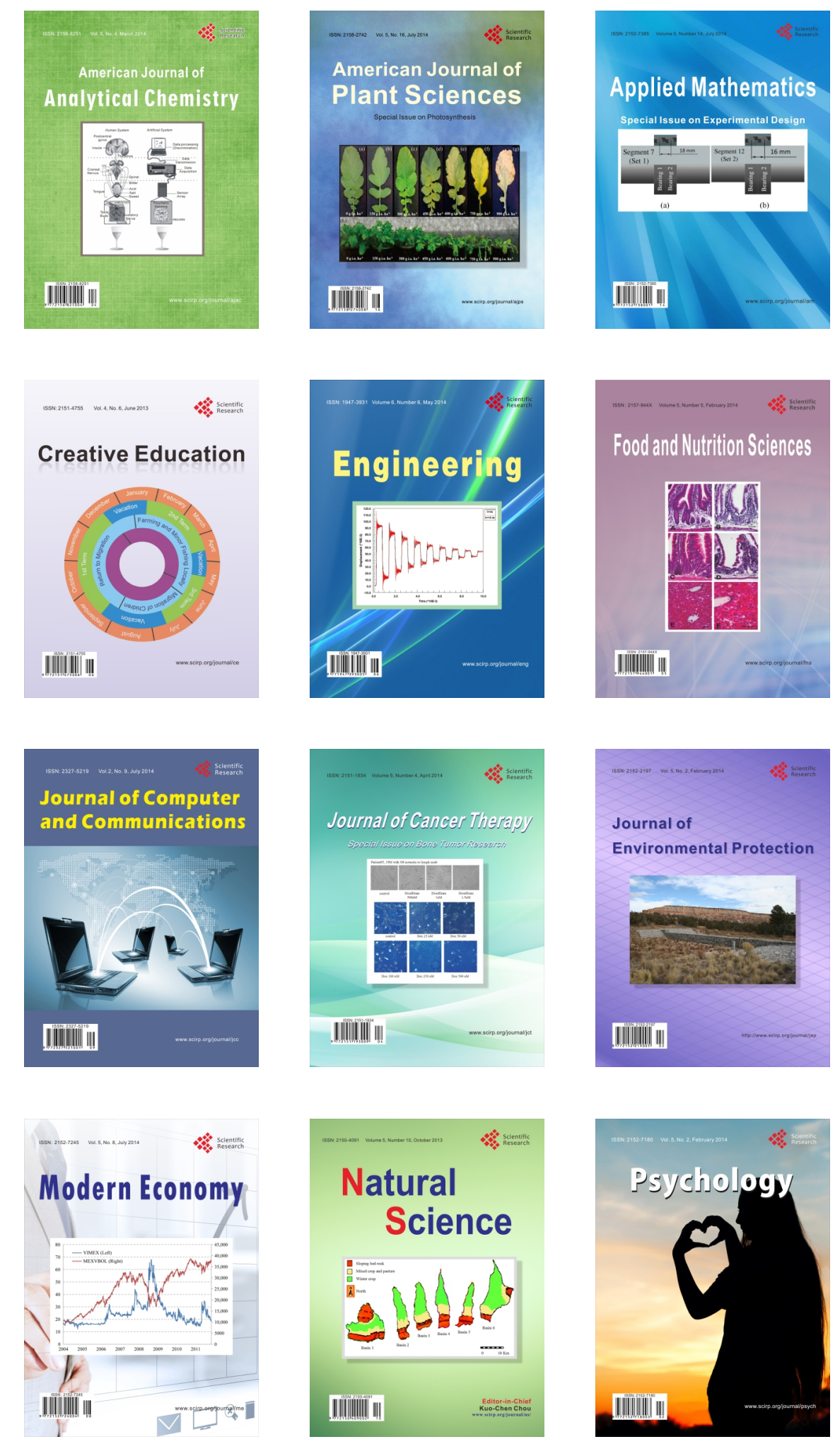